KRITIKĒ VOLUME ONE NUMBER ONE (JUNE 2007) i-ii

Editorial

\title{
Welcome to KRITIKE: An Online Journal of Philosophy
}

The Editor

K

RITIKE's editorial team would like to welcome you to the maiden edition of the journal. KRITIKE is an independent Filipino journal composed of academics who are alumni of the Faculty of Arts and Letters, University of Santo Tomas, Manila. KRITIKE seeks to bring together and publish the works of academic philosophers, graduate students of philosophy, and aspiring scholars who have strong philosophical inclinations in a scholarly journal with an open-access format.

The idea of online open-access journals is relatively new to Filipino scholars, especially in philosophy. The technology we call the "internet" has profoundly changed the face of academic publication; today it is possible to publish quality research with less financial constraints and notwithstanding rigorous editorial processes. We believe that it is an imperative for us, serious academics and students of philosophy, to take advantage of this technological advancement.

KRITIKE is our way of responding to the need for an academic forum suitable for aspiring young academic philosophers in the country and to the growing popularity of the internet as a legitimate medium of research. The journal is grounded on the belief that the flow and dissemination of ideas or theories should be free. It is mainly for this reason that the founding editors decided to launch an open-access journal where seasoned and aspiring scholars from all over the Philippines and the rest of the world can share their critical opinions on philosophy and its impact on society and our individual lives. We hope that the materials published by the journal will provoke the minds of the readers and will initiate dialogue and healthy debate which, from a dialectical stance, are crucial in the development of Filipino philosophy.

The name we have chosen for the journal-KRITIKE—comes from the Greek verb krinein, which means to discern. Hence, kritike means the art of discerning or the art of critical analysis. Every form of philosophizing (Continental, Analytic, Western, or Eastern) is, in one way or another, a critique of something. Hence, being critical seems to be an attitude common to all philosophical traditions. Indeed, the meaning of philosophy is critique and to be philosophical is to be critical! 


\section{ii EDITORIAL}

In this inaugural issue, we have collected essays from a wide range of philosophical themes-ranging from critical theory of society (broadly construed), deconstruction, phenomenology, down to process philosophy.

The first essay by Melanie P. Mejia is a very informative and lucid discussion of some common (mis)conceptions about Muslim religion and culture by examining the issues of gender equality, polygamy, and divorce. She concludes that the Muslim religion is in essence not oppressive to women and that the oppression is a result of some misinterpretations of the Qur'an. Meanwhile, Paolo A. Bolaños, via the German critical theorist Theodor Adorno, challenges the notion that an artwork is created merely for the sake of entertainment. Bolaños highlights Adorno's aesthetics of redemption and argues that art has a critical role to play in society. Art when it becomes selfconscious becomes a counter-culture that can expose the ills of what Adorno calls the culture industry.

In "The Paradox of Ipseity and Difference: Derrida's Deconstruction and Logocentrism," Roland Theuas S. Pada offers an in-depth analysis of the maverick French philosopher Jacques Derrida's deconstructive approach to the notion of logocentrism. The paper underscores the relation between the concepts of "ipseity" and "difference," and Pada argues that talking about beings in their ipseity and difference paves the way for the possibility of an ontology based on the singularity of being. Pada's gloss on Derrida's philosophy creates some interesting tensions (consciously or unconsciously) with the thoughts of Nietzsche, Heidegger, Levinas, and Deleuze, and could serve as a springboard for further explorations of the concepts of subjectivity and difference.

Fleurdeliz R. Altez, in the fourth essay of this issue, inquires into another French thinker's, Emmanuel Levinas, thoughts on evil. Levinas' call of infinite responsibility is defined by his discourse on violence and human suffering. Altez discusses how reflecting on violence and suffering prefigured Levinas' philosophical involvement with metaphysics, epistemology, and human affairs. Further, Altez remarks that answering for the Other involves an engagement with an axiological source.

Pope John Paul II (Karol Wojtyla) was known by many as a charismatic Catholic Pope, but only few recognized him as a philosopher. With his recent death in 2005, there has been renewed interest in his philosophical works, especially in the Philippines. Two paper submissions on Wojtyla's phenomenology of the acting person have made it to the first issue of the journal. The first one, written by Dean Edward A. Mejos, is a critique of the problem of alienation. Mejos maintains that Wojtyla's philosophy engages with the problem of alienation and defines the condition as the denial or misrecognition of a person as a subject. Alienation blurs the true essence of the individual, thereby encumbering the ability of the person to participate in a community of others; what is at stake is the recognition of the humanity of others and the actualization of an individual's very own humanity. Wojytla, Mejos thinks, provides us with a guide in overcoming alienation. Peter Emmanuel A. Mara, in the second paper on Wojtyla, endeavors to understand 
the human being as a subject and a person. Mara emphasizes Wojtyla's method of marrying Thomism and phenomenology. Personhood and subjectivity, Mara notes, point to the inner structure of the human being, they comprise the essence of the human being inasmuch as man has natural propensities (personhood) and the ability to act with other fellow human beings (subjectivity).

Finally, Rev. Fr. Salvador P. Barcelona, in a theocentric paper entitled "The Changing Image of God in Process Philosophy," examines the possibility of perceiving the dynamic image of the Christian God through the philosophy of the American philosopher of religion Charles Hartshorne. Following Hartshorne, Barcelona argues that the metaphysics of substance, a perspective common to classical metaphysics, is an inadequate way of accounting for the dynamic character of God. Barcelona further argues that since making sense of the world is essentially perspectival, there is no absolute way of accounting for the true character of God.

We are very pleased to offer you our first installment of essays. Alongside our mission of bringing together the works of scholars from across the whole range of philosophical topics and schools of thought in a congenial, open, and academically healthy forum is our vision of expanding our frontiers. We are keen in inviting more people from other institutions to join our editorial board. This is just the beginning. The independent character of KRITIKE is directed towards expansion.

This maiden edition of the journal would have not been possible without the help of a number of individuals. So allow me to end this editorial with a note of thanks to these people. To the members of our advisory board: Dr. Alfredo P. Co for offering his home as venue for our first organizational meeting and for his invaluable advices and Bro. Romualdo E. Abulad, SVD, for helping us with the review process. I would also like to express my gratitude to Dean Edward A. Mejos and Rowena Azada-Palacios for their support.

Again, welcome to KRITIKE! 